\title{
A Model for Assessing Investments in Intensive Grazing Technology
}

\author{
P.N. WILSON, D.E. RAY, AND G.B. RUYLE
}

Abstract

The financial profitability of intensive grazing management techniques such as short duration grazing (SDG) and the Savory Grazing Management (SGM) has received very little attention in the range management or economics literature. Most research has emphasized variables which measure technical rather than economic efficiency. A conceptual economic model is presented which illustrates the importance of the management factor in determining the optimal stocking rate and profitability of cell grazing practices. Empirical results yield internal rates of return on an after-tax basis for a $\$ 10,000$ grazing cell for $11-40 \%$ assuming cow herd productivity is maintained at, or increased above, pre-adoption levels. As cell costs increase and stocking rates increase, ranch profitability declines and increases respectively in almost all cases. The principal determinant of long-run pronts is found to be livestock productivity since this factor has a greater impact on profitability than stocking rate levels or cell investment costs. Increased stocking rates with intensive grazing technology do not insure increased profits unless concurrent improvement in range, livestock, and business management practices are adopted.

Key Words: economics, investment, cell grazing

Economic analyses of range improvements and grazing systems have received minimal attention in the range management and agricultural economics literature (Quigley et al. 1984, Crom 1985). Range scientists have emphasized technical efficiency while economists have concentrated their efforts primarily on identifying optimal stocking rates relative to economic returns (Pope and McBryde 1984). Unfortunately, range management techniques such as controlled burning, mechanical brush control, reseeding, the application of herbicides, as well as most grazing systems, have had questionable positive impacts upon the rancher's cash flow position and longer-run financial condition (Garoian et al. 1984). In recent years there has been increased interest in the adoption of intensive grazing management practices which, it is argued, can place the ranch in a stronger economic position. The widespread interest in intensive grazing management stems largely from the proclaimed benefits of the Savory Grazing Method (SGM) (Savory and Parsons $1980 \mathrm{a}, \mathrm{b}$ ). Unfortunately, many ranchers have constructed grazing cells and increased stocking rates without necessarily changing other management practices. Because this paper is not an analysis of SGM, we choose to refer to cell grazing technologies as intensive grazing management (IGM).

The use of rotational grazing practices similar to IGM can be traced back to the late 18th century (Smith 1956). The scientific foundations of IGM were thoroughly developed by Voisin (1959) for tame pastures during the 1950 's with implementation on rangelands first occurring in Africa (Goodloe 1969). The impact of IGM on soil erosion and infiltration (McCalla et al. 1984, and Gamougoun et al. 1984), range (forage) productivity (Heitschmidt et al. 1982a,b), and livestock production (Taylor et al. 1980, and Jung et al. 1985) has been generally positive from an ecological and biological perspective, although long-term environmental impacts are still being evaluated.

The economics of IGM has received much less attention although increased profitability should usually be the rancher's

\footnotetext{
Authors are assistant professor, Department of Agricultural Economics; professor, Authors are assistant professor, Department of Agricultural Economics; professor,
Department of Animal Sciences; and assistant professor, Range Management Division, School of Renewable Natural Resources, University of Arizona, Tucson 85721.

The authors wish to thank E.L. Smith, Jr., for his helpful comments.

Manuscript accepted 31 March 1987.
}

adoption/nonadoption decision variable (Savory and Parsons 1980c). Conner and Chamberlain (1985) calculated the breakeven stocking rate for short duration grazing (SDG) under alternative beef price and conception rate assumptions where the breakeven level was defined as the stocking rate which equated total net returns for the conventional and SDG systems. Their synthetic budget analysis revealed that in order to implement SDG under reasonable price and conception rate assumptions, a breakeven stocking rate increase of $65 \%$ over the conventional rate was required. A 1-year study of a specific grazing cell in Hawaii found that the adoption of intensive grazing technology yielded a 475pound increase in beef produced per acre $(32 \mathrm{~kg} / \mathrm{ha})$ in a stocker steer enterprise (Leung and Smith 1984). This productivity increase, even during a period of below-average rainfall, generated a $90 \%$ internal rate of return on a $\$ 36,500$ grazing cell investment.

The objectives of this paper are to extend the economic research of IGM into an investment framework by (1) presenting a conceptual economic model for evaluating the adoption of IGM technology, (2) developing an empirical model for analyzing grazing cell investments, and (3) using this methodology to analyze the aftertax profitability of IGM investments under alternative bioeconomic conditions. Economic tradeoffs between cell investment costs, stocking rate increases, and animal productivity are highlighted.

\section{A Conceptual Economic Framework}

Technical change takes place at the firm level when production practices are modified due to research results, from learning by doing, or by some combination of the two (Binswanger 1978). Technological change is evident when knowledge is applied to the production process and results in a change in the production function. Intensive grazing technology combines existing knowledge into a new framework for analyzing grazing and animal production problems and should be thought of as technological change.

Land-augmenting technology is embodied in new levels of capital and management which combine with land to increase the effectiveness of the variable inputs (Zilberman 1984). In the case of IGM, fencing and management are combined, with a fixed amount of land, to produce a higher level of productivity in the cow herd (variable input). Land is augmented by being able to graze the range more intensively without degrading the resource base.

The adoption of IGM can be viewed as a two-stage process (Caswell and Zilberman 1983). Assume there are 2 grazing technologies available to the rancher, traditional $(0)$ and intensive grazing (1). The production functions for the 2 technologies can be expressed as $Y_{i t}=f\left[m_{i t} X_{i t}\right]$ where $Y$ is the production level (pounds of beef produced) for the ith technology in period $t, f(\bullet)$ is a continuous production function with $\mathrm{f}^{\prime}>0$ and $\mathrm{f}^{\prime \prime}<0$ representing the first and second derivatives respectively, $m$ is the management effectiveness parameter in the time period $t$ for technology $i$ where $m_{i t}>0$, and $X_{i t}$ is the stocking rate for the ith technology in time period $t$. The general profit maximization solution for the rancher can be found by,

$$
\left.\max _{\delta_{i t}, X_{i t}}=\sum_{i=0}^{1} \delta_{i t}\left[P f\left(m_{i t} X_{i t}\right)\right)-r_{t} X_{i t}-F_{i t}\right]
$$

subject to

$$
\delta_{0}+\delta_{1}<\text { and } \delta_{1}, \delta_{0}>0
$$


where $P$ is the output price, $r$ is the variable cost per head of maintaining the cow herd, and $F$ represents the fixed cost of technology $\mathrm{i}$. The decision variables are $\delta_{\mathrm{i}}$, the share of land devoted to technology $i$, and $X$, the stocking rate.

This profit maximization problem can be simplified by assuming all available land is devoted to the ith technology. This alternative formulation can be expressed as,

$$
\max _{X_{i t}} \pi_{i}=P_{t} f\left(m_{i t} X_{i t}\right)-r_{t} X_{i t}-F_{i t}
$$

where the necessary and sufficient conditions for profit maximization for the ith technology are $P_{t} m_{t} f^{\prime}=r_{t} P_{t} m_{t} f^{\prime \prime}<0$, respectively. Comparative static results yield $d^{*} X_{i t} / d r_{t}<0, d X^{*} i t / P_{t}>0$ and $\mathrm{dX}^{*} \mathrm{it} / \mathrm{dm}>0$ where $\mathrm{X}^{\boldsymbol{*}_{\mathrm{it}}}$ is the optimal stocking rate for the $\mathrm{ith}$ technology in period $t$. The first optimality condition implies that the stocking rate should be increased until the economic value of the marginal increase in the stocking rate $\left(\mathrm{Pmf}^{\prime}\right)$ is equal to the effective price or cost of obtaining and maintaining an additional animal unit (replacement heifer). The comparative static results imply that the optimal stocking rate will decrease, increase, and increase as the price of replacement heifers, the price of feeder calves, and the management input increase, respectively.

Management effectiveness under IGM is assumed to be greater, hence $m_{0}<m_{1}$ for all $t$. By assuming $m_{0}=1$, then the optimal stocking rate for traditional technology will be less than the stocking rate under IGM. But if $m_{0}=m_{1}$, optimal stocking is equal for the 2 technologies $\left(X_{0}^{*}=X^{*}\right)$ and substituting these values into equations (2) produces lower profits under IGM because of the increase in fixed costs associated with this technology (i.e. $F_{0}<F_{1}$ ). This conceptual model indicates that economically optimal stocking rates increase as the management ability of the rancher improves. It also implies that the management input under IGM must be greater than it is with more conventional grazing technology for the IGM investment to be profitable. This final statement is a hypothesis which should be tested empirically under alternative range and geographic conditions.

The second stage of the adoption process, given the economically optimal stocking rate under each technology, is to compare the profitability of each grazing system (i.e. $\pi *_{0}$ versus $\pi * 1$ ). However, to most ranchers, potential variability in profits under each technology is an important decision factor as well. Economic gains obtained from adopting IGM could be offset by increased variability in profits $\left(\sigma_{1}{ }^{2}\right)$ associated with the new grazing technology. The only clear case where IGM will be adopted over the conventional grazing technology is when expected IGM profits are greater than expected profits from the conventional technology, $E\left(\pi_{1}\right)>E\left(\pi^{9}\right)$ and $\sigma_{1}^{2} \leq \sigma_{0}^{2}$. Otherwise the preference tradeoff of the rancher between risk and income will determine the selection of the technology. Investment decisions should be made after the decision maker has compared these risk/return tradeoffs under varying investment cost, stocking rate and livestock performance assumptions.

\section{Analytical Method}

Using the conceptual model as a guide, a simple financial investment model can generate quantitative insights into the profitability of the IGM adoption decision. Assume a rancher in the southwestern region of the United States has a 200-head cow herd on 8,000 acres of land. The rancher, using a conventional restrotation grazing plan, realizes a return above variable cash costs of $\mathbf{R}_{\text {ot }}$ dollars per cow in the cow/calf operation in year 1. Expected returns above variable cash costs using IGM technology are expected to be $R_{1 t}$ with stocking rates of $X_{0 t}$ and $X_{1 t}$ for conventional and IGM grazing, respectively. The net revenue $\left(R_{t}\right)$ obtained for adopting IGM technology is $R_{t}=R_{I t} X_{1 t}-R_{0 t} X_{0 t}$. The two components which are important in this relationship are the added stock level $\left(X_{1 t}-X_{0 t}\right)>0$ and the bioeconomic efficiency measure $\left(R_{1 t}-R_{0 t}\right) \geq 0$. This latter component serves as a proxy for the management effectiveness parameter in the conceptual model. Both relationships influence the profitability of adopting the new grazing technology.

Combining this information with grazing cell and replacement heifer investment costs, and tax and financing data, the after-tax net present value $\left(\mathrm{V}^{*} \mathrm{~T}\right)$ of the IGM investment for year $\mathrm{T}$ can be found by solving:

$$
V_{T}^{*}=\sum_{t=0}^{T}\left[R_{t}-\left[M T R_{t}\left(R_{t}-I_{t}-D_{t}\right)\right]+C S_{t}-P I_{t}\right]\left(1+i_{i}\right)^{-t}
$$

where the marginal tax rate is MTR, I is the interest cost for financing the replacement heifers and the grazing cell, D is the depreciation for purchased heifers and the cell, CS is the Agricultural Stabilization and Conservation Service (ASCS) cost share amount, PI represents the principal and interest payments on debt and $i$ is the discount rate or opportunity cost of capital for year $t$. Setting $V_{T}^{*}=0$ and solving for $i$ reveals the internal rate of return (profitability measure) of the IGM investment. Necessary assumptions for the empirical analysis include: (1) the ASCS contributes $\$ 3,500$ in cost share funds to the construction of the grazing cell in each of the first 2 years of the 10-year planning period, (2) the cell is financed by borrowing $100 \%$ of the net cost of the cell at a $10 \%$ interest rate for 5 years, and (3) the replacement heifers are purchased for $\$ 500$ each and financed at $10 \%$ for 3 years. Tax regulation changes made in the Tax Reform Act of 1986 concerning depreciation, Section 179 deductions and investment tax credit have been incorporated into this analysis.

\section{Results and Discussion}

The bioeconomic efficiency measure $\left(R_{1 t}-R_{0 t}\right)$ reflects the difference between returns above variable costs per cow for IGM as compared to the conventional grazing method. Numerous range, livestock and business management factors can influence the size and sign of the bioeconomic efficiency measure (BEM). For this analysis, cow performance will be the key consideration. BEM will be negative if returns per cow decline due to poorer nutrition, lower calving rates, and/or lower weaning weights after the adoption of

\begin{tabular}{|c|c|c|c|c|c|c|c|c|c|}
\hline \multirow[b]{3}{*}{ Stocking rate increase ${ }^{1}$} & \multicolumn{9}{|c|}{ Cell Investment Cost } \\
\hline & \multicolumn{3}{|c|}{$\$ 10,000$} & \multicolumn{3}{|c|}{$\$ 20,000$} & \multicolumn{3}{|c|}{$\$ 40,000$} \\
\hline & S-5 & $\$ 0$ & $\$ 5$ & $\$-5$ & $\$ 0$ & 55 & $\$-5$ & S0 & 55 \\
\hline $\begin{array}{r}25 \% \\
50 \% \\
75 \% \\
100 \%\end{array}$ & $\begin{array}{l}1.9 \\
4.6 \\
5.4 \\
5.7\end{array}$ & $\begin{array}{l}17.7 \\
12.6 \\
11.3 \\
10.7\end{array}$ & $\begin{array}{l}39.3 \\
21.3 \\
17.5 \\
15.8\end{array}$ & $\begin{array}{c}-10.1^{3} \\
-1.9 \\
0.9 \\
2.4\end{array}$ & $\begin{array}{l}0.8 \\
4.8 \\
6.2 \\
6.9\end{array}$ & $\begin{array}{l}12.3 \\
11.8 \\
11.6 \\
11.6\end{array}$ & $\begin{array}{r}-21.4 \\
-10.6 \\
-5.8 \\
-3.1\end{array}$ & $\begin{array}{r}-13.8 \\
-5.3 \\
-1.4 \\
0.8\end{array}$ & $\begin{array}{r}-0.7 \\
-0.2 \\
2.9 \\
4.7\end{array}$ \\
\hline
\end{tabular}
IGM. BEM will be zero or positive of cow performance stays the

Table 1. Internal rates of retum for alternative investment costs, stocking rate increases, and bioeconomic efficiency measures per cow, 1987.

'Equivalent to $\left.\left[\mathbf{X}_{\mathbf{1 t}}-\mathbf{X}_{\mathbf{0 t}}\right) / \mathbf{X}_{\mathbf{0 t}}\right] \times 100$.

2Equivalent to $\left(\mathbf{R}_{1 \mathrm{t}}-\mathbf{R}_{0 t}\right.$ ) where $\mathbf{R}_{0,}$ equals $\mathbf{\$ 8 0}$ in returns above variable costs per cow (U.S.D.A., 1982; Conner and Chamberlain, 1985).

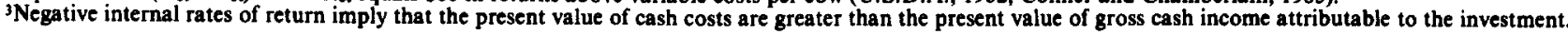


same or improves under the new technology. Range deterioration could also influence the size and sign of BEM, particularly in the long run since poorer quality and less forage can also reduce cow performance.

The results presented in Table 1 demonstrate the interactions between cell investment cost, cow productivity, and stocking rate. Assume 8 to $9 \%$ is an acceptable rate of return on a grazing cell investment. Clearly from this analysis, grazing cells which are lower in cost yet functional are preferred to higher cell investments. The $\$ 40,000$ cell investment generates below-acceptable returns for all stocking rates and $B E M$ values. If $B E M>0$, then these higher cost cells become more attractive to the rancher at higher stocking rates $(>50 \%)$. The $\$ 20,000$ grazing cell is a marginally profitable investment if $\mathrm{BEM}=\mathbf{0}$ and the stocking rate increase is greater than $50 \%$. Profitable rates of return also are realized for all stocking rate increases if $\mathrm{BEM}>0$. A $\$ 10,000$ investment with $\mathrm{BEM}>0$ generates a favorable rate of return at all stocking rate increase levels. However, internal rates of return fall below $6 \%$ even in these lower investment examples if cow performance declines.

Increased stocking rates improve profitability if $\mathrm{BEM} \leq 0$. For example, with the $\$ \mathbf{2 0 , 0 0 0}$ cell investment and $B E M=0$, a herd increase from 300 to 350 cows raises profitability by approximately $1.4 \%(4.8$ to $6.2 \%)$. Similar small increases for stocking rate increases occur throughout Table 1. When BEM $>0$ for the $\$ 20,000$ cell, internal rates of return actually decline marginally as the stocking rate increases. This somewhat counter-intuitive result arises because of the timing and size of after-tax cash flows as stocking rates increase. Additional after-tax income in future years does not offset the cost of replacement heifers during the first 3 years as the number of replacements increases. For BEM values of $\$ 0$ and \$5, Figure 1 illustrates the relationship between $V^{*}$ for

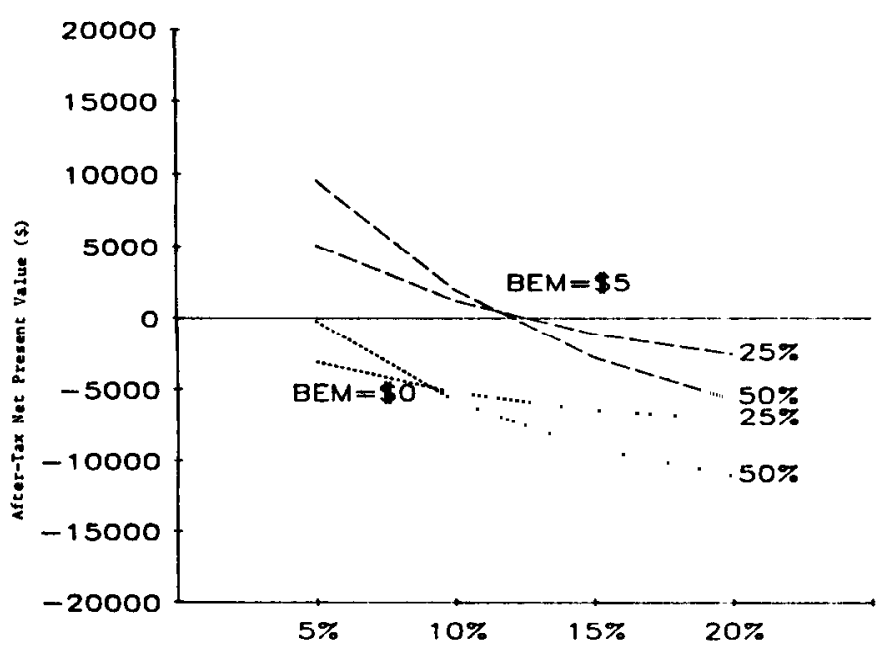

Discount Rate

Fig. 1. After-tax net present values for alternative discount rates, BEM values and stocking rate increases.

stocking rate increases of 25 and $50 \%$. The after-tax net present values eventually cross as future income is discounted more heavily. This intersection of the values for $V^{*}$ where BEM is equal to $\$ 5$ illustrates the relationship of the internal rates presented in Table 1. A stocking rate increase of $50 \%$ when BEM equals $\$ 5$ is preferred to a stocking rate increase of $25 \%$ when opportunity costs of capital are less than $12 \%$. Otherwise, the lower increase is preferred.

These results indicate that maintaining or improving cow herd productivity as stocking rates increase is far more important for profitability than increased stocking rates alone. This outcome can be seen by comparing the internal rates of return by reading horizontally across Table 1 . IGM technology is profitable if individual cow productivity is maintained or increased with the increased number of cows. It is critical that the rancher maintain or improve cow performance over time through increased monitoring of disease, nutritional and reproductive problems, as grazing cell technology is implemented. Improved business management practices such as recordkeeping, personnel management, and financial management also can increase BEM. These results also indicate that as the rancher's opportunity cost of capital increases, he will be better off improving individual animal productivity than investing in additional replacement heifers. Ranchers with fewer and loweryielding investment options would choose to increase stocking rates.

The critical nature of improved management can be demonstreated by using the concept of a learning curve. Suppose a rancher invests in a grazing cell $(\$ 20,000)$ and increases his stocking rate by $50 \%$ (200 to 300 cows). Assume he is inexperienced with IGM technology, therefore individual cow performance declines by $\$ 5$ the first year, which means that returns above variable costs on a per cow basis are $\$ 5$ less then they were with the conventional technology. However, in the second year BEM improves to \$0, and in years 3-10 the rancher improves individual cow productivity to a BEM value of \$5. If the rancher had failed to improve his management with a higher stocking rate he would have lost money over the planning period with a rate of return of $-1.9 \%$ (Table 1). However, by learning to use IGM technology his internal rate of return on his investment is $8.9 \%$. In our experience this learning-curve type of process has been commonplace with the successful adopters of IGM technology.

\section{Concluding Remarks}

Land-augmenting technology can produce increased production per unit of land but not be a profitable investment due to higher capital costs. Properly managed intensive grazing technology represents a promising alternative to more traditional range management paradigms. The economic viability of IGM will depend upon the degree of improvement and sustainability of range improvement and the rancher's ability to maintain or increase animal performance.

It is hypothesized based on the results of the conceptual and empirical models that improved management is an essential input in converting increased stocking rates into higher profits. Future research should concentrate on the soil, forage, and animal production relationships and how these factors influence the profitability of the IGM technology. The preceding analysis recognizes the importance of these factors but does not explicitly incorporate them into the analytical models. Integrated, biocconomic rescarch efforts are required to accurately measure the expected returns and risks associated with this grazing technology.

\section{Literature Cited}

Binswanger, H.P. 1978. Induced technical change: Evolution of thought. p. 13-43. In: H.P. Binswanger and V.W. Ruttan, ed., Induced innovation: technology, institution and development, Johns Hopkins University Press, Baltimore.

Caswell, M.F., and D. Zllerman. 1983. The economics of land augmenting irrigation technology. Giannini Foundation Working Paper No. 265, Univ. of California, Berkeley.

Conner, J.R., and P.J. Chamberlain. 1985. Development of breakeven analysis for use in short duration grazing system investment decisions. Selected paper presented at the Annu.Meetings of the Southern Agr. Econ. Ass., Biloxi, Miss., Feb. 3-6, 1985.

Gamouzoun, N.D., R.P. Smith, M.K. Wood, and R.D. Pieper. 1984. Soil vegetation, and hydrologic responses to grazing management at Fort Stanton, New Mexico. J. Range Manage. 37:538-541.

Crom, R.J. 1985. Range economics research (the national interest). Western J. Agr. Econ. 10:110-115.

Garoian, L., J.R. Conner, and C.J. Scifres. 1984. Economic evaluation of fire-based improvement systems for macartney rose dominated rangeland. J. Range Manage. 37:111-115.

Goodloe, S. 1969. Short duration grazing in Rhodesia. J. Range Manage. 22:369-373. 
Heitschmidt, R.K., Gordon and J.S. Bluntzer. 1982a. Short duration grazing the Texas experimental range: Effects on forage quality. J. of Range Manage. 35:372-374.

Heitschmidt, R.K., D.L. Price, R.A. Gordon, and J.R. Frasure. 1982b. Short duration grazing at the Texas experimental ranch: Effects on aboveground net primary production and seasonal growth dynamics. J. Range Manage. 35:367-371.

Jung, H.G., R.W. Rice, and L.J. Koong. 1985. Comparison of heifer weight gains and forage quality for continuous and short-duration grazing systems. J. Range Manage. 38:144-148.

Leung, P., and B.J. Smith. 1984. Economics of intensive grazing: A case in Hawaii. Research Extension Series 045, College of Tropical Agricultural and Human Resources, Univ. of Hawaii.

McCalla, G.R., II, W.H. Blackburn, and L.B. Merrill. 1984. Effects of livestock grazing on sediment production, Edwards Plateau of Texas. J. Range Manage. 37:291-294.

Pope, C.A. and G.L. McBryde. 1984. Optimal stocking of rangeland for livestock production within a dynamic framework. Western J. Agr. Econ. 9:160-169.

Quigley, T.M., J.M. Skovlin, and J.P. Workman. 1984. An economic analysis of two systems and three levels of grazing on ponderosa pinebunchgrass range. J. Range Manage. 37:309-312.
Savory, A., and S.D. Parsons. 1980a. The Savory grazing method. Rangelands 2:234-237.

Savory, A., and S.D. Parsons. 1980b. Ecological principles of short duration grazing. Beef Cattle Sci. Handb. 17:209-214.

Savory, A., and S.D. Parsons. 1980c. The economics of the Savory grazing method. Beef Cattle Sci. Handb. 17:222-227.

Smith, J.H. 1956. Some early advocates of rotational grazing. J. of Brit. Grassl. Soc. 11:199-202.

Taylor, C.A., M.M. Kothmann, L.B. Merrill, and D. Elledge. 1980. Diet selection by cattle under high-intensity low-frequency, short duration and Merrill grazing systems. J. Range Manage. 33:428-434.

U.S. Department of Agrlculture. 1982. Beef cow/calf enterprise budgets. Econ. Research Serv., Washington, D.C.

Voisin, A. 1959. Grass productivity. Translated by C.T.M. Herriot, Philosophical Library, Inc., New York.

Zilberman, D. 1984. Technological change, government policies, and exhaustible resources in agriculture. Amer. J. Agr. Econ. 66:634-640. 